\title{
China's Belt and Road Initiative: A Global Model for an Evolving Approach to Sustainable Regional Development
}

\author{
Muhammad Khalil Khan ${ }^{1, * \mathbb{C}}$, Imran Ali Sandano ${ }^{2,3}$, Cornelius B. Pratt ${ }^{4}$ and Tahir Farid ${ }^{5}$ \\ 1 College of Media and International Culture, Zhejiang University, 866 Yuhangtang Road, \\ Hangzhou 310058, China \\ 2 Department of International Relations, University of Sindh, Jamshoro 76080, Pakistan; \\ Iimran110@usindh.edu.pk \\ 3 Nontraditional Security and Peaceful Development, Zhejiang University, 866 Yuhangtang Road, \\ Hangzhou 310058, China \\ 4 Lew Klein College of Media and Communication, Temple University, Philadelphia, PA 19122, USA; \\ cornelius.pratt@temple.edu \\ 5 Department of Applied Psychology \& Behavioral Science, Zhejiang University, 866 Yuhangtang Road, \\ Hangzhou 310058,China; tahir_khattak@zju.edu.cn \\ * Correspondence: khan@zju.edu.cn; Tel.: +86-132-8215-2291
}

Received: 1 October 2018; Accepted: 12 November 2018; Published: 16 November 2018

\begin{abstract}
China's Belt and Road Initiative (BRI) is a cornucopia of international projects that offer mammoth opportunities for more economic cooperation and deeper regional integration primarily among emerging economies. BRI is providing new drivers of sustainable economic growth in China and of cross-border trade, along with the reimagined land and "Maritime Silk Road". The initiative focuses on restoring global balance and on expanding universally beneficial and inclusive relationships. This article argues that the forces of globalization are so pivotal to Eurasia, where development opportunities can propel the region toward a more comprehensive socioeconomic integration, that governments in that region need to provide more support that ensures the continuing success of BRI. In essence, BRI is a critical tool for peaceful development that is resulting in massive investments in infrastructure, that is facilitating economic development, and that is promoting shared governance. This article provides theoretical perspectives on BRI as a beachhead for sustainable regional development. It also highlights BRI programs and projects that have emerged as an internal and external policy framework for an openly inclusive "win-win" cooperation model based on shared development and on communities of shared interests.
\end{abstract}

Keywords: Belt and Road Initiative; shared development; shared future; shared globalization

\section{Introduction}

China believes in the equality of all countries, large and small, and we don't believe some countries should lead others-rather than talking about leadership, we should really be talking about responsibility.

—Wang Yi, Chinese Foreign Minister [1].

The political values and economic norms of the international system are in flux. Arguably, after the Cold War era, the global financial crisis (GFC) led to the resurgence of nationalism and protectionism in global politics. Political developments in the United Kingdom that led to Brexit and those from President Donald Trump's antiglobalization rhetoric, "America First", are evidence 
that globalization is being overrun by nationalism, protectionism, and isolationism in the West [2-4]. Some argue that globalization is heading toward extinction [5]. Globalization has reached its zenith and is in the process of moving toward reverse globalization. Many Western countries increasingly acknowledge that the standard practices associated with globalization have lost traction in the wake of the GFC. Therefore, Western powers, particularly the United States, are erecting more tariffs to protect their domestic industries with the result that "international trade is in its worst period in 30 years" [6]. Meanwhile, China's worldviews on the free flow of commerce remain unencumbered, but the status quo is no longer consistent with U.S. and the European Union trade and political preferences. Their commitments to the free flow of trade have pivoted toward self-serving impulses in the form of trade protectionism [3].

In some quarters, globalization is viewed as an antithesis to sustainability, in light of growing populism and of trade protectionism in the West. But hallmarks of shared globalization are emerging in Asia. The Western and particularly the U.S. unilateral policies to protect U.S. interests first prompted China to marshal its resources to revamp and reconstruct the world order in an attempt to contain U.S. hegemony or to make it more difficult to execute [7]. China has effectively responded to neoliberalism's crises and took effective measures to redefine and reorient globalizing practices by, among other things, providing a new alternative model of shared development for mutual benefits through its Belt and Road Initiative (BRI). Many believe that BRI is a gigantic effort to provide an alternative pathway for growth in developing nations, which are searching assiduously for strategies and models to develop their economies while securing and protecting their sovereignty, their political choice and their way of life in a widely hegemonic, Western-centric world [8-11].

Today, the global power dynamic is changing in response to the resurgence of a new multipolar world order [12]. Thus, the U.S. "unipolarmoment" is being diminished and its clout as a global superpower is being challenged [13]. For example, Ferguson [14] noted that the increasing dominance of the East in the 21st Century has replaced the Western-oriented world order as we observe "the descent of the West" and "a reorientation of the world" toward the East [15]. China's peaceful rise in the East and its robust economic growth make it the next global superpower [14,16]. The era of U.S.-led globalization is heading to its logical end. "Anglobalization" was replaced by "Ameriglobalization" and the United States took over global leadership from the United Kingdom during the last century. Now China is poised to take over that "mantle of global leadership" as its robust economic performance has become a source of inspiration to developing economies worldwide [4,11,17].

With a population of nearly 1.4 billion people, China has the world's second-largest economy, accounting for the largest part of global growth since the GFC in 2009 [18]. Through its expanding influence on global economic organizations (e.g., the International Monetary Fund (IMF), World Bank, Asian Development Bank), China is asserting its global economic vision by building institutions and supporting initiatives such as the Asian Infrastructure Investment Bank (AIIB); Shanghai Cooperation Organization (SCO); and BRICS (Brazil, Russia, India, China, and South Africa). It is also participating actively in existing global institutions such as the World Trade Organization (WTO), the IMF, and the United Nations Security Council (UNSC) to better safeguard its national interests $[19,20]$. China's commitment to assuming responsibility for institution building (e.g., setting up a multilateral bank, AIIB, to secure and provide funding for BRI projects undertaken in collaboration with U.S. allies (i.e., UK, Australia, Israel, and South Korea) indicates its readiness to provide alternative resources to needy nations and to nudge the World Bank toward investing more in infrastructural projects, well beyond the quotidian endorsement of institutional-reform agendas [20-22]. AIIB is a channel for delivering BRI's capital and technical services for implementing infrastructural projects in the region. Therefore, BRI, along with other key international groups or projects such as BRICS, New Development Bank (NDB), AIIB, SCO and the National Silk Road Fund (NSRF), could usher a "new era of globalization" that might create opportunities for joint economic cooperation, sustainable development and a deeper regional integration that could lead further to a new era of a shared development model of globalization [23,24]. 
The purpose of this article is to provide a theoretical understanding of the concept of shared globalization through a shared development model. It also highlights China's motivations for developing BRI, which is emerging as an internal and external policy framework for an inclusive and openly "win-win" cooperative, global-development model based on shared interests.

\section{China's Regional and Global Impact}

China's transformation from a regional economic power to a global powerhouse, its efforts in human development, and its robust economic performance are common knowledge in the international community. Some countries expect China to assume a greater role and responsibility in international economic institutions and in global governance [8]. Additionally, the major geopolitical transition and dramatic changes in the Western political landscape have also encouraged China to initiate an alternative model of human development, as the balance of economic and political powers is shifting from the West to the East, in light of the 21st century being dubbed the Asian century. The Chinese leadership knows that the next 20 years is of "great strategic importance" for China's peaceful rise as a major global power $[7,8,15-17,25-29]$. In recent years, China has demonstrated greater enthusiasm to strengthen its political influence and economic integration with neighboring countries via vibrant inter-regional connectivity projects under the wider umbrella of BRI [30]. Therefore, BRI is often labeled as Beijing's strategic effort to boost its soft image as a constructive actor in its neighborhood through a shared model of economic and social success that respects the sovereignty of and the equality among nations [31,32]. It is embedded in the "Chinese dream" to "leverage China's growing economic power and influence [along its periphery] in order to strengthen and expand cooperative interactions, create an integrated web of mutually beneficial economic, social and political ties, and ultimately lower distrust and enhance a sense of common security" [11].

The West has exhibited mixed responses to suspicions over the overt intentions of BRI and AIIB. Western scholars, for example, believe that China's investments in Asia, Africa, the Middle East, Europe, and Latin America are a part of its strategic maneuvers to leverage its political and economic influence at global level $[33,34]$. Washington is concerned that Beijing might replace the Western-dominated financial system with AIIB and BRI, the fulcra of a China-centered international economic system. However, The Economist noted that "China has won, gaining the support of American allies not just in Asia but in Europe, and leaving America looking churlish and ineffectual" [34]. But concerns among ASEAN countries are still persistent, as many see the new Maritime Silk Road as a reflection of China's emerging naval power and growth in maritime capabilities at the global level [30]. The U.S. assumes that BRI projects will be used for political and military causes (e.g., continuing the fortification and militarization of the South China Sea and China's military base in Djibouti); and that they will jeopardize the international trade and security in the Indian Ocean region $[24,35,36]$.

China is enhancing its commercial footprints, establishing and expanding its political influence and military presence in other regions bordering the Red Sea and in Asia [36]. Scholars argue that BRI is a "guerre de course" strategy of offensive mercantilism that will enable China to enter in foreign markets [24,36]. There are also concerns related to financial risks of US $\$ 900$ billion in Chinese investment and repayment of debts to China by some Eurasian countries [37,38]. In particular, recent events in Sri Lanka and Malaysia, which are both buried in debts to China, have raised many questions about the potential benefits of BRI to recipient countries. Sri Lanka failed to repay its debt to China and was forced to sign over its strategic Hambantota port to China Merchants Port Holdings Company on a 99-year lease to mitigate the unpaid debts. This development has been seen as a critical threat to Sri Lanka's sovereignty [38]. Malaysia canceled a key multibillion-dollar project of a high-speed railway link to Singapore to "avoid being declared bankrupt" [39]. Similar concerns have also emerged over the China-Pakistan Economic Corridor [40].

In sum, BRI is entwined with geoeconomics and geopolitical goals developed to supplant Western globalization, to limit U.S. global dominance, and to strengthen China's influence globally [25,41]. However, from China's perspective, BRI is a "win-win" outcome that will instigate a new phase of 
globalization, and will provide a new engine to economic and industrial growth through infrastructural development and regional connectivity [42]. China asserts that BRI is envisioned to construct a harmonious world based on mutual understanding, mutual satisfaction, and mutual benefit integrated with core Western values of peace, freedom, justice, and democracy. These values are based on co-humanity, collectivism, and multiculturalism, rather than on individualism, to make the world a more harmonious global village [17].

The large-scale investment in inter-regional infrastructural ventures are much needed but risky from political and economic perspectives in the region as many of the countries are economically weak, underdeveloped and politically unstable [30]. Therefore, it is important to develop a theoretical model as a basis for analyzing how BRI can engender an alternative vision of globalization and sustainable development based on mutual cooperation and shared development [43].

\section{An Overview of the Belt and Road Initiative}

BRI is a major strategic component of China's "go global" policy announced by the President Xi Jinping in 2013 [44]. The initiative has its roots in the ancient Chinese philosophy of "Silk Road Spirit", which advocates promoting peace, cooperation, openness, inclusiveness, mutual learning, and mutual benefit among all civilizations [45]. BRI is often considered a game-changer that will connect the land-locked economies of Asia, Europe, and Africa. The "Belt" consists of vibrant networks of roads and railways that will connect the Western part of China to Western Europe via Central Asia, Iran, Turkey, Russia, the Caucasus, and the Balkans. Besides, linking Eurasia by land, the "21st Century Maritime Silk Road" is proposed to connect China with South Asia, Southeast Asia, the Middle East, Africa, and Europe through a strip of seaports through the South China Sea, the Indian Ocean, and the Mediterranean Sea [25,46,47]. The Chinese government is committed to developing six economic corridors: China-Pakistan Economic Corridor, China-Indochina Peninsula Economic Corridor, Bangladesh-China-India-Myanmar Economic Corridor, China-Mongolia-Russia Economic Corridor, China-Central and West Asia Economic Corridor, and the New Eurasian Land Bridge along with parallel networks of oil and gas pipelines, telecommunication links, and high-speed fiber optic cables for better transportation and connectivity among transregional nations (Figure 1) [48,49]. Chinese authorities believe that transportation infrastructure is "the first step in creating an economic corridor that will integrate the landlocked economies of the Eurasian hinterland and tie them more tightly to China" [47].

The strategic importance of BRI for China can be gauged from a generous allocation of US \$1 trillion for the project as seed money in 2013. The initiative has already attracted an additional US $\$ 8$ trillion to facilitate infrastructural development across BRI countries, particularly in Asia. In late 2017, China also enshrined BRI into its Communist Party constitution to seek further international acceptance [50,51]. Chinese scholars argue that BRI is not only limited to infrastructural development; it will also generate policy and cultural dialogues among nations. It will promote infrastructural connectivity, facilitate unimpeded trade, and ease financial support to the developing world that would eventually promote China's image as a new responsible global power [52,53]. In fact, China is developing a comprehensive strategy of communication and connectivity, "ranging from politics to finance, from infrastructure and trade to culture and religion to construct zones of economic cooperation and centers of cultural exchanges" [25].

BRI is a long-term commitment that needs collaborative efforts from all participating countries to work together for a more inclusive, balanced development. The developing countries lack financial capital as well as the infrastructure, which are prerequisites for economic and industrial development [54]. China possesses both the financial resources of more than US $\$ 3.5$ trillion in foreign exchange reserves and a vast experience in infrastructural development. Therefore, BRI promises massive infrastructural development that provides the bases for economic and industrial prosperity in the region [55]. BRI-related projects involve $70 \%$ of the global population, $75 \%$ of its known energy reserves and territory, $25 \%$ of global trade, and $55 \%$ of global GDP [49]. 
However, there is a need to evaluate China's discourses on win-win outcomes and mutual benefits for all. This paper analyzes critically the BRI framework and provides useful policy guidelines toward making it a win-win outcome under the broader concept of shared globalization.

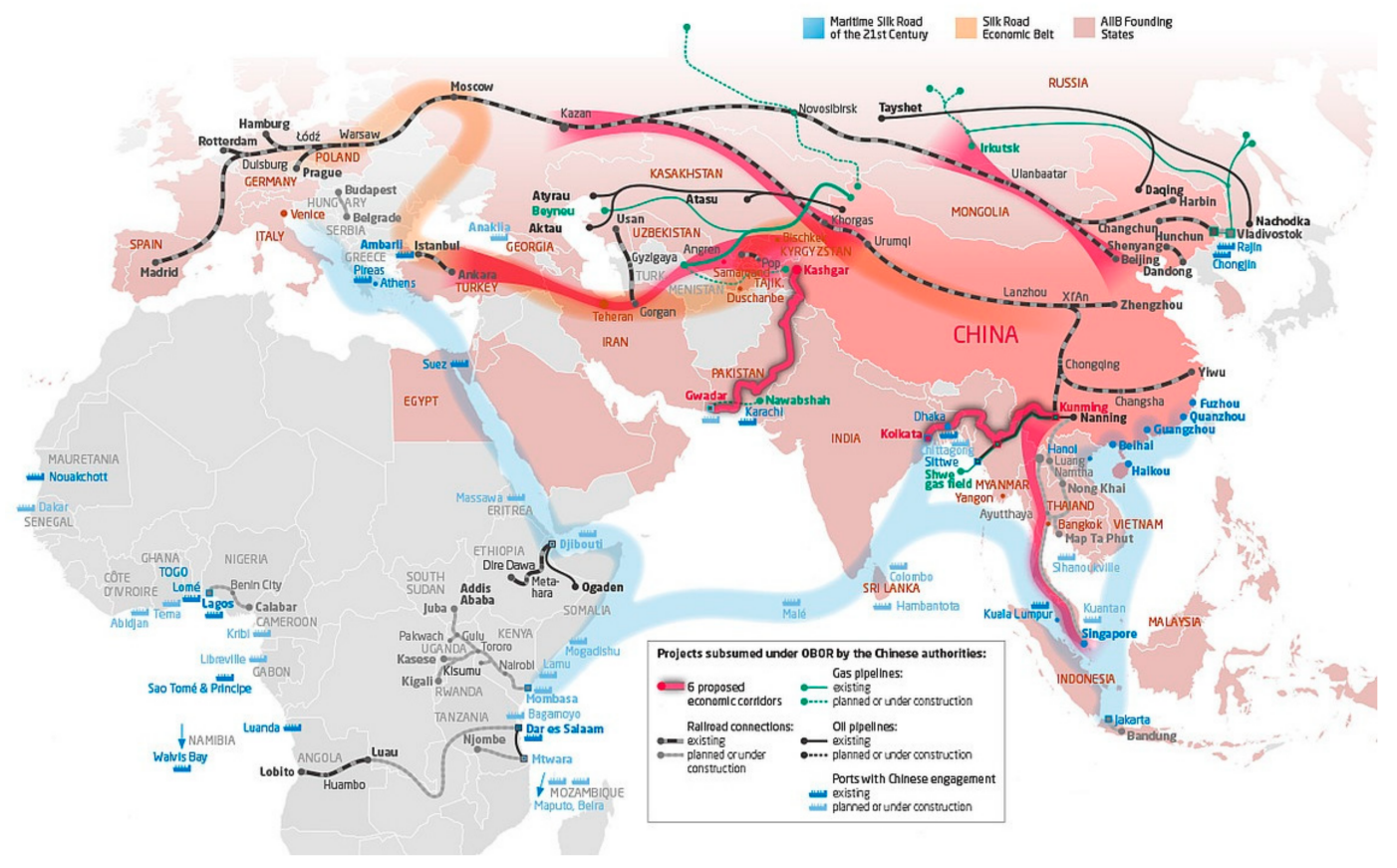

Figure 1. Mapping China's Belt and Road Initiative (Source: Mercator Institute for China Studies, 2015).

\section{Theoretical Framework-Globalization}

Even though globalization is a common topic in the academic literature, it has not engendered a consensus on its extent and definition. In fact, globalization is a transformative process of nation-states that embodies both socioeconomic and political linkages that extend from financial deregulation to technological innovation. These drivers have succeeded in reining in trade barriers, in encouraging trade flows between and among nation-states, in stimulating growth in the global financial markets, and in expanding the purviews of multinational companies. Innovations in information technology also facilitated the development of unusual patterns that changed global sourcing. Globalization limits government involvement in both economic and social policy with a growing emphasis on free market with a goal to make the world a "global village" [56,57].

Globalization has created an interconnected web of mutual interdependence among different actors, societies, economies, and nations at multicontinental distances by mediating the free flow of people, ideas, information, good and capital [58-60]. It has three main dimensions: social, political, economic. Economic globalization is often considered as a motor behind the whole process; however, few argue that political and social globalization are the most important elements of sustainable globalization [57,61]. Economic globalization describes the free flow of capital, goods, services, and information, as well as the perception of market exchanges. Political globalization characterizes government politics, while social globalization facilitates and exchanges information, ideas, images and people [57].

There is disagreement on the efficacy of these dimensions: that globalization has promoted economic prosperity in some countries while it has enfeebled the economy of weak states. There are arguments in support for and against globalization as "good" or "bad" but it has significantly contributed to the economic growth in many countries.

Dreher's empirical study on panel data of 123 countries from 1970-2000 indicated that globalization affects the economic performance and growth in many developing countries [57]. There is a "hyper-globalist perspective", which argues that the global market is completely unified, 
and national economies have mostly become inessential. But, on the other hand, the "skeptical perspective of globalization" indicated that international practices have always existed, but that the national economies remained as a dominant factor within them [62]. However, gradually, the focus shifted on the process of complicated globalization that is based on the multidimensional practices with historical roots, including both change and continuity [63]. Higgots believes that "globalization is developing and by no means an irreversible process in which a range of state actors, international institutions and non-state actors such as multinational corporations, global social governments, and non-governmental organizations play increasingly significant roles" [64].

Much of the Western debate on globalization has always been sidelined by the role of developing countries, yet these countries account for a majority of the world's population. They have been severely affected by the Western global integration and economic liberalization through the burden of maintenance and structural modification programs; furthermore, they have never been close to the homogeneous process [65]. The implications of global integration have always remained diverse among countries. Some countries have been capable enough to establish export markets and to take part in global financial trade while others have found it a difficult undertaking.

Simply put, globalization facilitates capitalism in two ways: "capitalism" and "corporate capitalism". Capitalism is a process of global transformation, a key driver of societal changes. On the other hand, corporate capitalism is a process beyond the boundaries of nation states, institutions, cultures, markets, and economies. It is logical, then, to conclude that the process of Western-promoted globalization involves a large number of contributing forces or factors such as technological innovations; abated domestic economies of the dominant West; wars; political and military pressures on the emerging economies of the developing countries; the demise of the former Soviet Union; the emergence of an alternative global system; the publicity of Western ideology; and the role of the United Nations (UN) and its agencies such as the World Bank, WTO, IMF and United States Agency for International Development [66]. Additional forces: the increasing expectations of people and their dreams for power-sharing with the grassroots in organizational and management democracy and the growing availability of cheap labor worldwide [66].

In a nutshell, globalization represents growing international economic interdependence and an exclusive increase in foreign direct investments, international trade, global movements of people, ideas, and technologies [67]. It has made possible the development of technologies, the liberalization of international investment regimes, the removal of trade barriers, and the softening of domestic regulations. The early wave of globalization boosted the global shift of services and manufacturing to some leading economic powers but decimated the economic development in the developing countries. However, some countries with extensive domestic and inward investment achieved remarkable growth, succeeded in reducing poverty, and improved the lives of millions of their citizens. But, on the other hand, globalization also increased the global poverty and inequality between the South and the North. Some countries did not overcome the obstacle and fell behind-an outcome of investment outflows with the loss of well-paying jobs [61].

The West, which, for decades, remained a proponent and a champion of free trade and globalization, has shown skepticism toward major cross-border military, political, and economic alliances [26]. It has always maintained a one-way road for exploitation and monopolization of the Third World, its cheap labor, and its financial markets. Thus, it is easy for the developed West to engage in a campaign against immigrants, blaming them for upstaging indigenous labor, and contributing to crime and terrorism. The U.S.'s recent unilateral withdrawal from UNESCO and President Trump's decision to withdraw the U.S. from the Paris Climate Agreement left the world in a precarious position. The U.S. is steadily moving away from globalizing practices toward a more nationalist, protectionist approach. On the other hand, China stood firm on its international commitments such as the Paris Climate Agreement, insisting on the need for a sustainable environment for future generations. There are severe environmental consequences of climate change, water shortage, 
unseasonal torrential rainfall patterns, and floods, necessitating national and global commitments to the future of a sustainable environment.

China seems committed to reorienting and reorganizing the decaying international world order and stands ready to share its development prowess with other countries, particularly BRI partners through a new model of shared development. China is attempting to enhance its friendship and cooperation with all countries based on five principles: (a) coexistence grounded in peace; (b) respect for sovereignty and for territorial integrity that is mutual; (c) noninterference in other countries' internal affairs; (d) nonaggression on all sides; and (e) equality and cooperation for mutual benefit. China acknowledges that successful implementation of BRI will bring shared prosperity, shared development, and win-win outcomes for all participating countries [68].

\section{Globalization-A Chinese Perspective}

China aims to develop a harmonious, win-win global society, a sustainable global village based on cooperation for mutual benefits, mutual respect of each other's political choice, state sovereignty and territorial integrity. China has learned a moral lesson from the adverse consequences of rejecting globalization and positive outcome after embracing it later. Therefore, China is sustaining globalization, but in a new form, labelled "Chiglobalization-a process of China-led global search for and a global enlightenment by an alternative mode of life for humanity on the basis of, but above and beyond, the Eurocentric model" [17].

China is building a new tone for international relations guided by the vision of innovation, mutual coordination, open and inclusive development [68]. It is building its own network for political and economic influence in global governance through BRI. China plans to recast a dated world order with a new form of shared globalization through BRI rather than extending its own social, political, economic influence [23]. Its strategy is to develop and modernize neighbors for peaceful coexistence and facilitate connectivity, and infrastructural development across the Eurasian countries. China acknowledges that successful completion of BRI projects will ultimately improve its impact on the global governance system $[7,27,69]$. However, there are concerns that strings are attached to this multibillion-dollar initiative [37-40]. Holslag termed the BRI as an offensive mercantilism strategy to protect China's domestic industries and to support them to reach foreign market by promoting exports to BRI countries, particularly by manufacturing industries that are plagued with overcapacity [37]. Brown argues that beneath overt narratives of development and cooperation, China is building infrastructure in BRI countries not only for transportation of goods but also of energy because it needs abundant energy to sustain its economic growth well into the future [50]. Fair and others termed BRI as a vague geopolitical plan, an economic "bubble," and frivolous infrastructural project that will eventually implode and leave economically fragile nations indebted to China [50,70]. China dismisses these Western arguments as an attempt by the West to contain its economic and political influence on the global stage [42].

In recent years, China has strengthened its economic stature and influence at the global level through its robust economic performance, unprecedented enthusiasm for global communication, growing worldwide presence, and global leadership with a new global vision of building a global community of shared interest, destiny, and responsibility. China denounces hegemony and power politics and believes in mutually constructive long-term relationships with all countries. Its diplomatic efforts are based on the Confucian principle of interpersonal relationship, characterized by benevolence and loyalty, contrary to U.S. diplomacy presented in the incendiary rhetoric of moral superiority in an attempt to satisfy short-term self-interest. China prefers development to security (development is contingent on establishing security regimes) whereas the U.S. prefers security to development (security is contingent on establishing an inclusive economic regime) [71].

China is wielding enormous influence at the center of the global stage. It has shown interest in developing a peaceful and a prosperous world. Its worldviews of global governance are based on equality, equitability, openness, and pluralism that are "more peaceful and harmonious" than was apparent in the preceding neoliberal world order [25]. China emphasizes collectivism, groupism, 
multiculturalism, pragmatism and does not embrace a uniform solution to every situation. China's diplomatic strategy is flexible and adaptable and enthusiastic about working hand-in-hand with all countries to "create a clean and beautiful world which enjoys lasting peace, universal security, common prosperity, openness and inclusiveness" [72]. While presenting a report to the 19th National Congress of the Communist Party of China in Beijing on 18 October 2017, President Xi Jinping asserted that "No country can handle the various challenges facing human beings on their own, while no country can retreat to an isolated island". The world should "stick together through thick and thin" and engage in more efforts to liberalize and facilitate global trade and investments, so as to make economic globalization "more open, inclusive, and balanced so that its benefits are shared by all" [72].

China's development model is not only limited to economic development but includes advocacy for deepening and sustaining a globally harmonious society for peaceful coexistence. China believes that economic prosperity could generate positive social changes in society. Ramo argues that "China is in the process of building the greatest asymmetric superpower the world has ever seen, a nation that relies less on traditional tools of power projection than any in history and leads instead to the electric power of its example and the bluff impact of size". China's development model emphasizes the use of economic stability and good governance to improve society, "an original goal of development economics that somehow got lost in the Washington-consensus-driven 1990s" [7].

\section{Method}

This article is strictly conceptual, in that it presents theoretical perspectives that have the potential to shed light on a fast-developing regional—and a global-model of development. It is neither a quantitative nor a qualitative investigation or analysis of BRI per se; rather, it is premised on the notion that assessments and evaluations of government policies and practices are a sine qua non for stocktaking on government actions, even absent empirical contexts and standard qualitative and mixed-methods research designs. Nonetheless, it is hoped that future research will gather empirical data to test rigorous propositions and research hypotheses, which will be grounded in part in the conceptual directions presented in this article.

That said, it must be noted that this article employed a nonsystematic content analysis of 120 official BRI-related statements issued by China's government officials (www.eng.yidaiyilu.gov.cn), from 1 September 2013 to 31 December 2017. The statements were in two categories: shared development and shared future.

\section{A Shared Globalization Model}

A shared globalization model is based on the Chinese philosophy of moral politics. Chinese leadership holds the view that Western power politics and hegemonic economic policies have exacerbated the gap between the North and the South, threatened the global environment, fueled political conflicts, and promoted terrorism worldwide [7]. Therefore, China should step forward to assume more responsibility in global governance that will create a more peaceful, developed and harmonious world, where everyone can live "meihaoshenghuo" (美好生活)—that is, a happy life [73].

The shared globalization model advocates mutual, sustainable development based on the idea of a "win-win" cooperation for equal benefits and advantages; it also guarantees state ownership and sovereign identity. It is more inclusive and balanced. It is equally beneficial for China's own economic stability and sustainable economic development in the regions as well. The idea of shared globalization seems similar to the "Peace of Westphalia" that advocates a system of equal and peaceful coexistence of sovereign states by safeguarding the interest of the "Other" [74]. BRI has potential to generate a new model of shared globalization based on "win-win cooperation" that offers the world a unique state of bigger openness, integration, and interdependence with a comprehensive approach to shared development and shared future. It proposes massive development opportunities through BRI, BRICS, NDB, AIIB, SCO, and NSRF [9]. When fully operational, BRI projects will give a unique impact on the sustainable development through shared globalization within Asia and outside world. 
The shared globalization is based on two main components (shared development and shared future), and both are connected (Figure 2).

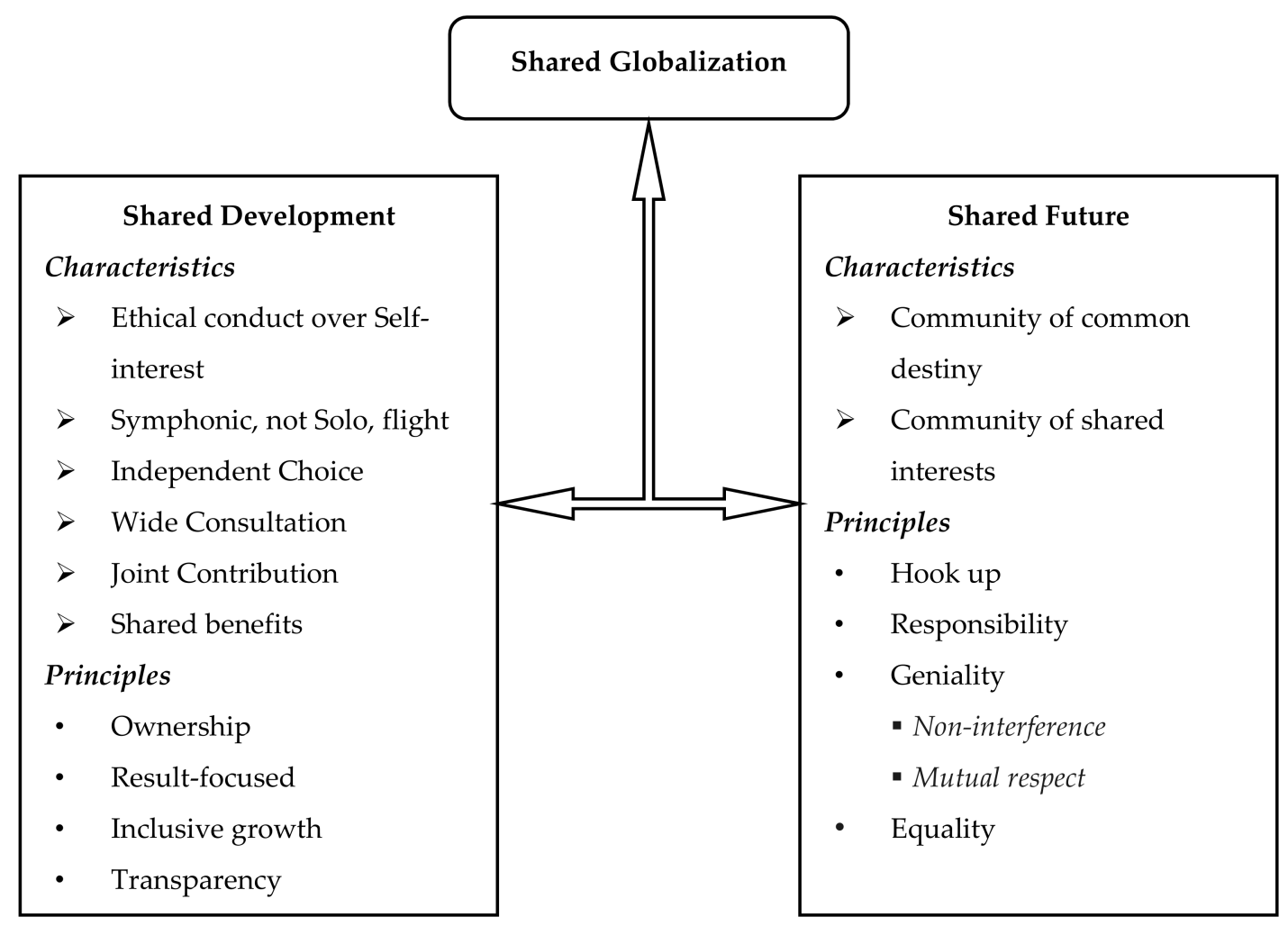

Figure 2. A conceptual model of shared globalization.

\subsection{Shared Development}

Shared development is the core component of shared globalization. President Xi Jinping coined the concept of shared development as the last of five development ideas. It is ranked fifth not because it is least important, but because it needs the prior success of the innovative development, coordinated development, green development, and open development concepts [75]. At the national level, the shared development concept fits in the fifth position; but at the global scale, it is important to approach with multidimensional ranges. Shared development is a process of endorsing justice before self-interests in developing the neighboring countries. President Xi Jinping clearly stated in its speech in the UN in September 2015 that "Facing the future, China will continue to give due consideration to both self-interests and justice, but as a matter of principle will give priority to justice over self-interests". He emphasized that China will "take a right approach to justice and interests by putting justice before interests" [76].

The shared development model offers assistance (both technical and financial) to partner countries and support to achieve faster-shared growth. It is a channel of active connectivity between countries and world regions to establish financial platform and regional infrastructural investment through land and sea. It would create a trusted environment that not only benefits China but also coordinating participants [77]. For example, during the last five years, despite a decrease in global trade, China's trade with BRI countries exceeded US $\$ 5$ trillion, with an average growth of $1.1 \%$ per annum. China has established 82 overseas free-trade and economic zones in BRI countries that attracted 4000 enterprises, generated US $\$ 2$ billion tax revenue and 244,000 local jobs [78]. There is also a significant improvement reported in the annual GDP growth of BRI countries. Particularly, the average GDP growth of European countries along BRI increased from $1.71 \%$ to $3.18 \%$, South Asia from $4.71 \%$ to $6.06 \%$ and Southeast Asia saw an improvement in its average GDP growth from 5.22\% to 5.34\% between 2013 and 2017 (Table 1). 
The World Bank policy research working paper has also endorsed successful trade integration between China and BRI's partner countries through backward and forward linkages and even facilitated the value-added export from the third country [79].

Table 1. The percentage of annual GDP growth in 65 China's Belt and Road Initiative (BRI) countries (Source: World Bank Data, 2018).

\begin{tabular}{|c|c|c|c|c|c|c|}
\hline Geographical Zones & Country Name & 2013 & 2014 & 2015 & 2016 & 2017 \\
\hline \multirow{3}{*}{ East Asia } & China & 7.76 & 7.30 & 6.90 & 6.70 & 6.90 \\
\hline & Mongolia & 11.65 & 7.89 & 2.38 & 1.24 & 5.88 \\
\hline & Average Growth & 9.71 & 7.60 & 4.64 & 3.97 & 6.39 \\
\hline \multirow{11}{*}{ Southeast Asia } & Brunei Darussalam & -2.13 & -2.35 & -0.57 & -2.47 & 1.33 \\
\hline & Cambodia & 7.36 & 7.14 & 7.04 & 6.95 & 6.81 \\
\hline & Indonesia & 5.56 & 5.01 & 4.88 & 5.03 & 5.07 \\
\hline & Laos & 8.03 & 7.61 & 7.27 & 7.02 & 6.89 \\
\hline & Malaysia & 4.69 & 6.01 & 5.03 & 4.22 & 5.90 \\
\hline & Myanmar & 8.43 & 7.99 & 6.99 & 5.87 & 6.37 \\
\hline & Philippines & 7.06 & 6.15 & 6.07 & 6.88 & 6.68 \\
\hline & Singapore & 5.11 & 3.88 & 2.24 & 2.40 & 3.62 \\
\hline & Thailand & 2.69 & 0.98 & 3.02 & 3.28 & 3.90 \\
\hline & Vietnam & 5.42 & 5.98 & 6.68 & 6.21 & 6.81 \\
\hline & Average Growth & 5.22 & 4.84 & 4.87 & 4.54 & 5.34 \\
\hline \multirow{6}{*}{ Central Asia } & Kazakhstan & 6.00 & 4.20 & 1.20 & 1.10 & 4.00 \\
\hline & Kyrgyzstan & 10.92 & 4.02 & 3.88 & 4.34 & 4.58 \\
\hline & Tajikistan & 7.40 & 6.70 & 6.00 & 6.90 & 7.10 \\
\hline & Turkmenistan & 10.20 & 10.30 & 6.50 & 6.20 & 6.50 \\
\hline & Uzbekistan & 8.00 & 7.79 & 8.00 & 7.80 & 5.30 \\
\hline & Average Growth & 8.50 & 6.60 & 5.12 & 5.27 & 5.50 \\
\hline \multirow{9}{*}{ South Asia } & Afghanistan * & 3.90 & 2.69 & 1.31 & 2.37 & 2.60 \\
\hline & Bangladesh & 6.01 & 6.06 & 6.55 & 7.11 & 7.28 \\
\hline & Bhutan & 2.14 & 5.75 & 6.60 & 7.99 & 6.82 \\
\hline & India & 6.39 & 7.41 & 8.15 & 7.11 & 6.62 \\
\hline & Maldives & 7.28 & 7.33 & 2.25 & 6.16 & 8.83 \\
\hline & Nepal & 4.13 & 5.99 & 3.32 & 0.41 & 7.50 \\
\hline & Pakistan & 4.40 & 4.67 & 4.73 & 5.53 & 5.70 \\
\hline & Sri Lanka & 3.40 & 4.96 & 5.01 & 4.47 & 3.11 \\
\hline & Average Growth & 4.71 & 5.61 & 4.74 & 5.14 & 6.06 \\
\hline \multirow{17}{*}{$\begin{array}{l}\text { Middle East and North } \\
\text { Africa }\end{array}$} & Bahrain & 5.42 & 4.35 & 2.86 & 3.22 & 3.88 \\
\hline & Egypt & 2.19 & 2.92 & 4.37 & 4.35 & 4.18 \\
\hline & Iran & -0.19 & 4.60 & -1.32 & 13.40 & 4.30 \\
\hline & Iraq * & 7.60 & 0.70 & 4.80 & 11.00 & -0.78 \\
\hline & Israel & 4.11 & 3.41 & 3.04 & 4.09 & 3.33 \\
\hline & Jordan & 2.83 & 3.10 & 2.39 & 2.00 & 1.97 \\
\hline & Kuwait & 1.15 & 0.50 & 0.59 & 3.55 & -2.87 \\
\hline & Lebanon & 2.64 & 2.00 & 0.82 & 2.00 & 2.02 \\
\hline & Oman & 4.37 & 2.75 & 4.74 & 5.38 & -0.27 \\
\hline & Palestine * & - & - & - & - & - \\
\hline & Qatar & 4.41 & 3.98 & 3.55 & 2.22 & 1.60 \\
\hline & Saudi Arabia & 2.70 & 3.65 & 4.11 & 1.67 & -0.74 \\
\hline & Syria * & - & - & - & - & - \\
\hline & Turkey & 8.49 & 5.17 & 6.09 & 3.18 & 7.42 \\
\hline & $\begin{array}{l}\text { United Arab } \\
\text { Emirates }\end{array}$ & 5.05 & 4.40 & 5.06 & 2.99 & 0.79 \\
\hline & Yemen * & 4.82 & -0.19 & -37.15 & -34.34 & - \\
\hline & Average Growth & 3.97 & 2.95 & 0.28 & 1.77 & 1.91 \\
\hline
\end{tabular}


Table 1. Cont.

\begin{tabular}{|c|c|c|c|c|c|c|}
\hline Geographical Zones & Country Name & 2013 & 2014 & 2015 & 2016 & 2017 \\
\hline \multirow{25}{*}{ Europe } & Albania & 1.00 & 1.77 & 2.22 & 3.35 & 3.84 \\
\hline & Armenia & 3.30 & 3.60 & 3.20 & 0.20 & 7.50 \\
\hline & Azerbaijan & 5.80 & 2.00 & 1.10 & -3.10 & 0.10 \\
\hline & Belarus & 1.02 & 1.72 & -3.83 & -2.53 & 2.42 \\
\hline & $\begin{array}{l}\text { Bosnia and } \\
\text { Herzegovina }\end{array}$ & 2.35 & 1.15 & 3.08 & 3.14 & 3.03 \\
\hline & Bulgaria & 0.86 & 1.33 & 3.62 & 3.94 & 3.56 \\
\hline & Croatia & -0.65 & -0.10 & 2.35 & 3.17 & 2.78 \\
\hline & Czech Republic & -0.48 & 2.72 & 5.31 & 2.59 & 4.29 \\
\hline & Estonia & 1.94 & 2.89 & 1.67 & 2.06 & 4.85 \\
\hline & Georgia & 3.39 & 4.62 & 2.88 & 2.85 & 4.99 \\
\hline & Hungary & 2.10 & 4.23 & 3.37 & 2.21 & 3.99 \\
\hline & Latvia & 2.43 & 1.86 & 2.97 & 2.21 & 4.55 \\
\hline & Lithuania & 3.50 & 3.54 & 2.03 & 2.34 & 3.83 \\
\hline & Macedonia & 2.93 & 3.63 & 3.84 & 2.92 & 0.02 \\
\hline & Moldova & 9.40 & 4.80 & -0.40 & 4.50 & 4.50 \\
\hline & Montenegro & 3.55 & 1.78 & 3.39 & 2.95 & 4.30 \\
\hline & Poland & 1.39 & 3.28 & 3.84 & 2.86 & 4.55 \\
\hline & Romania & 3.53 & 3.08 & 3.97 & 4.82 & 6.95 \\
\hline & Russian Federation & 1.79 & 0.74 & -2.83 & -0.22 & 1.55 \\
\hline & Serbia & 2.57 & -1.83 & 0.76 & 2.80 & 1.87 \\
\hline & Slovak Republic & 1.49 & 2.75 & 3.85 & 3.32 & 3.40 \\
\hline & Slovenia & -1.13 & 2.98 & 2.26 & 3.15 & 5.00 \\
\hline & Timor-Leste & -11.00 & -26.05 & 20.88 & 0.82 & -8.00 \\
\hline & Ukraine * & -0.03 & -6.55 & -9.77 & 2.31 & 2.50 \\
\hline & Average Growth & 1.71 & 0.83 & 2.49 & 2.19 & 3.18 \\
\hline
\end{tabular}

* War-affected countries.

These indicators suggested that China's BRI initiative is not a "solo" but a "symphony" of all partners. It is a common development initiative that will be implemented on equal-footed consultation. China will respect the independent choice of all participating countries and will be sensitive to their comfort level [80]. Xi Jinping has repeatedly asserted that BRI is a joint development initiative and "China will follow the principle of wide consultation, joint contribution, and shared benefits. The programs of development will be open and inclusive, not exclusive. They will be a real chorus comprising all countries along the routes, not a solo for China itself" [81].

The coordinating participants would create regional integration networks, which are an open phase of shared development. This thriving attitude could boost peace and prosperity within and outside the region. Shared development has long-term global implications for Western neglected developing countries. It depicts much more flexible shared economic growth arrangements globally. It demonstrates a state of shared world development in which the real goal of globalization would be achieved. Although it is under the explorative and experiment process, the ultimate result is the shared growth trends. For further understanding, four key principles characterize shared development concept: (a) ownership, (b) result-focused, (c) inclusive growth, and (d) transparency.

First, partnership of shared development can only be accomplished, when the ownership is given to participating countries. The ownership of the host countries over their development strategies and policies is critical for successful partnerships. This means that shared development ought to align with participant countries through their own policies, priorities, and systems. However, shifting of ownership of Hambantota port to China Merchants Port Holdings Company in Sri Lanka certainly raised questions on the actual ownership of BRI projects [38].

Second, focus on result ensures that shared development should have prominent impacts on reducing inequality, eradicating poverty, facilitating human development, and improving the capabilities and capacities of participating nations. These two principles are related to the intention to 
increase focus on development results. Therefore, if all the participating countries are agreed on such principles, then that could provide more support to the shared development model and will boost the ownership of member states through their own policies and priorities.

Third, inclusive growth is another core principle of the shared development model. It explains a stronger engagement and recognition of state and nonstate development actors, including civil society. The active involvement of these agents in any national system requires more time and effort for shared development. Therefore, inclusive growth can only be achieved through required trust, openness, and mutual respect for effective partnerships in support of shared development goals.

Fourth, transparency is more than an essential tool of, and a foundation for, accountability of BRI projects. The transparent and equal information on resources and project objectives, terms, and conditions provide the bases for mutual evaluations of outcomes of shared development. Mutually transparent accountability could provide expected benefits to participating nations, citizens, organizations, and shareholders. These two principles are related to the country-led transparent and inclusive framework by which shared development is monitored and mutual accountability endorsed. However, there are concerns in the newly elected governments of Pakistan and of Malaysia over transparency in the state-to-state agreements related to BRI projects that should be addressed to derive maximum benefits from them $[39,40,82]$.

In sum, these four principles are the essential elements of the shared development model and will boost the independent ownership of shared development, its policies, and its practices. These principles will play a significant role in efforts to achieve sustainable development and derive substantive results. The transparent system of shared supervision for proper monitoring, evaluation, communication, and results, along with scaling up the support of the host country to strengthen its national capacities and various investment resources, will ensure compelling results from the shared development model. An effectively shared development has the potential to pivot horizontal collaboration among various countries toward shared globalization.

\subsection{Shared Future}

In November 2012, the 18th National Congress of the Communist Party of China proposed the concept of "a community of shared future for all humankind". Thereafter, President Xi Jinping highlighted the concept of a shared future on many international and national forums. The concept is mainly designed to help and solve the key problems faced by humankind. It reflects the Chinese perception of global responsibility, which seeks to leave its mark on international politics. China views that concept as a fundamental part of its 5000-year-old civilization [83]. In fact, it is an innovative development approach to the traditional Chinese principles in the new era of shared globalization, where all nation-states are interconnected, and joint collaboration is a likely path of promoting shared development for shared future.

China believes that "a community of shared future for all humankind" would be a guideline for the world in the 21st century. The idea was also echoed in the UNSC and adopted in the form of a UN resolution on 17 March 2017. This acknowledgment indicates China's efforts in, and global responsibility for, shared globalization. President Xi Jinping, in his historic speech in the UN, said that "there is only one Earth in the universe and we mankind have only one homeland. It is the only home to mankind, so to care for and cherish it is the only option for mankind". He iterated: "We should not only think about our own generation but also take responsibility for future ones. All countries should jointly shape the future of the world, write international rules, manage global affairs and ensure that development outcomes are shared by all" [73].

In the current wave of shared globalization and shared development, the shared future can be understood as four key principles. The first is hookup-that is, the argument of shared future emphasizes ideas that bind the international community, bridge differences and split by prioritizing a shared future over divided endowment. The second is responsibility-that is, a focus on responsibilities that China believes would be appropriate for shared globalization and shared 
development, which ultimately create opportunities for both national and international community. The third is the ethics of geniality, which emphasizes noninterference and mutual respect that recognize the peace and prosperity of all participating nations through shared globalization. The fourth is equality, which seeks, for mutual benefits, fairness and trust in relationships among all stakeholders. The vision of a shared future enables the international community to recognize national, regional and global responsibility. Shared globalization and shared development are the essential elements of a shared future, which would transform the dynamics of the international community and bring it together. BRI is an effort toward "a community of shared future for all humankind" and indicates the spirit of Chinese diplomatic characteristics and responsible attitude for "win-win" cooperation.

\section{China's Motivations for BRI}

China claims that BRI is an attempt to promote international cooperation and to encourage globalization. However, scholars termed it China's strategic initiative, with many more objectives. First, the development of China is at a crossroads. It is restructuring and upgrading its economic initiatives from factor-intensive and export-orientation to a more innovative, sustainable and balanced path. These forces are pushing it to pursue a new and active role in global markets $[78,79,84]$. Some scholars argue that the BRI is "a tool for promoting national economic development by boosting exports, enhancing access to natural resources, and providing support to important domestic industries" [47]. Others see it as a government effort to relieve the overcapacity in certain Chinese capital-goods industry, particularly in construction-oriented industrial sectors [11].

Second, China's interior and Western landlocked provinces are lagging in development. Noteworthy is Xinjiang province, where China faces social unrest, terrorism concerns, and ethnic conflicts. China believes that the economic prosperity of the region will contribute to the peace in the province, where ethnic Uyghurs complain about the social, political and economic deprivation. Now, China wants to speed up development in the western region. BRI is likely to stimulate the economic activities in the Western region as it will connect China's landlocked Xinjiang province to the energy-rich Central Asia and the Middle East through road and sea routes [85]. Therefore, Chinese leadership believed that BRI is equally important for China's own economic development and social stability as well.

Third, China is focusing on building symmetrical relationships with its neighbors. That will ensure a peaceful local environment for its continuing economic growth. China wants to make friends, not enemies, out of its neighbors because it is surrounded by a complex geographical area and major nations with diverse history, culture, economy, political and security situations. It is essential for China to keep the local environment tranquil for its continuing increase in its profile. Therefore, China is hoping to build a "prosperous neighborhood" through BRI [7,27,69].

Fourth, after attaining a sustainable economic growth, China is looking for its due role in the global economy and hoping to develop a new cooperative international system for global governance. Through BRI, China is aiming to develop trust among nation by ensuring the mutual respect and shared interest for mutual benefits, a strategically motivated effort to strengthen the China's peripheral diplomacy and to build "a new type of major country relations" both of which are based on mutual respect, mutual development and mutual cooperation for mutual benefit, a win-win approach to the global politics, economy and security $[11,15,27,76]$. BRI is China's strategic push toward fulfilling the "Chinese dream" of the greater role of China in global governance. China's peaceful development, its power diplomacy and its ambitions to build a community of common destiny to protect world peace and promote shared development depends on the effective implementation of this strategic initiative $[11,86]$.

Fifth, China is the world's second- and fourth-largest importer of crude oil and of natural gas, respectively. It requires an undisrupted supply of energy to sustain its unprecedented economic growth. China seeks to fortify its energy security by reducing its dependence on the Strait of Malacca, which is susceptible to U.S. blockade. Therefore, it is developing an alternative energy corridor through BRI to 
improve its safe access to vital energy resources by constructing pipelines between China and Central Asian countries, and building railway lines, pipelines and road networks through China-Pakistan Economic Corridor to transport more sustainable fuel from the Middle East and Africa [19,46].

Sixth, China's corridors on economic development and its impact on the global environment will possibly explain its pathway to the sustainable development of the region. China's unprecedented economic growth in the last two decades has raised serious environmental issues for China and for the rest of the world. In recent years, Beijing has been receiving red alerts for environmental pollution. Therefore, China is shifting its coal-based industries to more sustainable fuels (e.g., natural gas) to curtail $\mathrm{CO}_{2}$ emissions and to improve its environmental quality. In addition, China is also aiming to transfer its heavy-polluting and energy-intensive manufacturing industries to the more competitive and relatively lower costs labor markets in BRI countries [19]. Several nongovernmental organizations note that China is undertaking measures to ensure its own industry is an active player in the green revolution by, for example, relocating its polluting industries to less developed countries. An example: China has moved its cement industry to Tajikistan, whose government lacks transparency in meeting international environmental standards $[87,88]$. China should look into an alternative way out of this problem [46]. However, there is hope that European countries (e.g., Germany, England, France and Australia, as founding members of the AIIB), will play a key role in maintaining the international environmental standards in the execution of AIIB-funded projects. Through BRI, China has improved its environmental quality by reducing $54 \%$ of air pollution in Beijing in 2017, compared with the 2016 level. China also experienced a 50\% reduction in coal consumption between 2013 and 2018 [89]. The country is working on its national action plan for future sustainable environment and fulfilling its international commitment regarding the sustainable environment (e.g., the Paris Climate Agreement) despite the U.S. withdrawal from the Paris Climate Agreement. Reportedly, China will achieve its 2020 carbon intensity objectives set in the Paris Climate Agreement ahead of schedule as $\mathrm{CO}_{2}$ emission per unit of economic growth dropped to $46 \%$ in 2017, compared with its original carbon intensity in $2005[89,90]$.

Seventh, China has developed grand diplomatic and economic strategies in the form of BRI not only to sustain its domestic economic growth but also to enhance its political and economic stature in global governance system by neutralizing US dominance of the global economy and minimizing its influence to contain China's regional and global interests [90]. However, China's foreign policy is based on peaceful cooperation and has never shown an imperialistic attitude toward any nation-state. Its economic growth is also based on mutual benefits. China believes that these initiatives would contribute to its own development and expand areas where its interests are consistent with those of the partner nations. It wants to secure its own development and respond strategically to the legitimate concerns of other developing countries. According to standard economic and trade rules, China wants market access and safeguards for the (legal) rights and interests of its partners. It wants shared development through enhancing the capacity of BRI partners to engage in their own independent development and to improve the lifestyle of their own people. That may be a critical step toward narrowing the gap between the South and the North. China insists that it will never seek profit at the expense of others or move its fracas toward others [91]. These motives show that the time is right for China to demonstrate shared globalization for equity, economic growth, poverty reduction, human development, and social and cultural respect [75].

Eighth, the ancient Silk Roads on sea and land also provided significant development and prosperity to the Asian, European, and African countries for thousands of years. BRI is a "Silk Road Spirit", which endorses peace and cooperation, mutual learning and mutual benefit, openness, and inclusiveness, and shared cultural heritage of all participating countries. It proposes encouraging economic cooperation among countries by promoting the arranged free-flow of economic features and the productive allocation of resources. BRI runs through the continents of Asia, Europe, and Africa, linking and stimulating the East Asia economic milieu at one end and developed Europe at the other, and encircling many countries with enormous economic development perspective. It also shows the 
strength to discover new models of shared globalization, which would create constructive contributions to world peace and development [92].

Finally, China seeks to revamp global geopolitics through BRI and to return Eurasia to its historical and significant position of the center of human civilization. The two great civilizations of East and West were connected with each other until the rise of the Ottoman Empire that cut off the ancient Silk Road [93]. That development pushed Europe to move toward the sea and lead globalization through colonization. The Eastern civilizations became conservative, and the world became "West-centric". However, the rising voices of antiglobalization rhetoric in the United States and the declining influence of Europe in the aftermath of Brexit, seem likely to nudge Europe toward returning to the center of the world through a revitalization of Eurasia.

\section{Conclusions}

BRI offers considerable potential in several areas: socioeconomic, political, cultural, environmental. This multibillion-dollar initiative has the potential to fulfill the global, sustainable development goals - that is, in creating jobs, in reducing poverty, in improving infrastructure and the economy through connectivity between countries, regions, and continents that makes it more universally beneficial and inclusive $[53,94]$. The $\mathrm{Xi}$ Jinping administration is projecting BRI as a symbol of China's foreign and economic policy with invaluable support from Chinese strategic analysts. However, some $[19,47]$ have termed this initiative as China's grand strategy to establish its political influence and rejuvenate at least its own neighborhood through economic development to neutralize the future risk of countervailing responses. There is some doubt that BRI might not enhance Beijing's political influence across Eurasia regions; however, there is little doubt that it would generate the huge development and economic activities across transregional states.

Other researchers [78,79] label BRI as "a new approach" to the global economic stability by reorienting the balance in economic globalization. China terms BRI as a "win-win" bilateral trade deal for mutual benefits that could redefine the patterns of "dependency" between North-South relations-“even if China's thirst for commodities appeared to replicate pre-existing trade patterns" $[95,96]$. The Chinese perspective of globalization seems different from the U.S-led neoliberal globalization. China believes in multilateral credit and strategic international economic collaboration to address the economic development, foreign investment, unemployment, and infrastructural development. This realization comes from its own comprehensive development experience which has produced quick results on the utmost in self-reliance through engagement of comparatively low-income people as suppliers of goods, services, and work. Socially, it indicates a model in which the management of both markets and the state was developed equally. In an economic context, BRI is not only planned to obtain economic profits as the neoliberals did but with "win-win" outcomes for participating countries as well. Politically, collaboration is open and comprehensive for all, without any political interference in participating countries' national affairs [97]. Thus, China aims to build a new comprehensive international platform on which shared globalization will benefit more people and regions [19].

BRI has already won the support of more than 100 countries and international organizations. Nearly, 50 cooperative agreements have been signed between China and other participating countries [98]. The participation of more than 130 countries (the world's major economies), including heads of state in a two-day forum, "The Belt and Road Forum for International Cooperation" on 15-16 May 2017, is evidence that China's discourses of peaceful cooperation for "win-win" gains are gaining international momentum and engaging the world in China's discourses. BRI has initiated a global communication system led by China, and its discourse is gradually gaining more currency. Through BRI, the country is exercising its impact on international communication and discourse to attain the "Chinese dream" of national prosperity, socialism, and nationalism [10].

BRI is expected to provide a favorable external environment to promote China's image as a responsible global power. BRI's joint initiatives can embrace the trend toward a multipolar world 
that might promote the idea of shared globalization, shared development, and shared future. It will promote the development of the international economy and will also provide a platform for developing countries to grow collaboratively - and symmetrically. The initiative aims to improve the connectivity among Asia, Europe, Africa, and Latin America by constructing multitier and composite connectivity networks and rationalized, diversified, independent, and sustainable development projects on those continents. In brief, it is intended to be based on a new logic of shared interests and common development, rather than on the conventional logic of the balance of power.

BRI will link deprived regions: Central Asia, West Asia, South Asia, and Southeast Asia. It will foster infrastructural innovation and development, which will help enhance the economic environment in participating countries and regions. This regional connectivity will complement the shared industrial, supply, and value chains, and engender Eurasian and Pan-Asian regional cooperation for shared development [77]. This will enhance global cooperation between China and the world. The initiative will not only help China move to much higher levels of development, but will encourage participating nations with shared growth momentum and will to create a more inclusive, shared global vision [23]. In essence, then, it will be a win-win for participating countries.

In conclusion, BRI is based on a core ideal of peaceful coexistence, mutual cooperation, sustainable development, and mutual benefit for all. It emphasizes five fundamental values: (a) systematic policy coordination, (b) free trade, (c) regional connectivity, (d) financial integration, and (e) people-to-people bonds. It also delineates three communities: community of shared interests, community of common destiny, community of responsibility [10]. These approaches reflect Chinese thinking about shared globalization, shared development and shared future, all of which create motivations for achieving global peace and development.

\section{Limitations and Suggestions}

This article is limited to a theoretical understanding of internal and external policy framework on BRI; it provides valuable insights into the new shared globalization model that is an inclusive, open "win-win" cooperation model based on shared development for a shared future. This article applies a nonsystematic content analysis to analyzing BRI, absent the gathering and analysis of empirical data. Therefore, we propose, for future research, an empirical study on BRI projects to evaluate the shared globalization model by measuring its characteristics and principles. In addition, future research should examine critically the much-celebrated concepts of "win-win outcomes" and "mutual benefits for all" by empirically evaluating select BRI's projects and their outcomes in participating countries.

Author Contributions: M.K.K. contributed to the literature review, the conceptualization and writing of the original article. I.A.S. helped in writing the initial draft. C.B.P. edited and proofread the final draft, and T.F. helped in formatting this article.

Funding: This research was funded by the 11th batch of special funds of the China Postdoctoral Science Foundation, grant number 2018T110583, which was awarded to the first author (M.K.K.).

Conflicts of Interest: The authors declare no conflict of interest.

\section{References}

1. Qinduo, X. China and the international order. China Plus. 2017. Available online: http://chinaplus.cri.cn/ opinion/opedblog/23/20170309/1280.html (accessed on 1 October 2018).

2. Crouch, C. Neoliberalism, Nationalism and the Decline of Political Traditions. Political Q. 2017, 88, 221-229. [CrossRef]

3. Brands, H. US Grand Strategy in an Age of Nationalism: Fortress America and its Alternatives. Wash. Q. 2017, 40, 73-94. [CrossRef]

4. Ahearn, R.J. Europe: Rising Economic Nationalism? Congressional Research Service, Library of Congress: Washington, DC, USA, 2006.

5. Sirkin, H.; Hemerling, J.; Bhattacharya, A. Globality: Competing with Everyone from Everywhere for Everything; Bussiness Plus: New York, NY, USA, 2008. 
6. Rong, F. Zhongguo Ying Daitou Fandui ‘Ni Quanqiuhua' Chaoliu. Beijing Ribao. 2016. Available online: http:/ / www.qstheory.cn/zhuanqu/bkjx/2016-07/27/c_1119288692.htm (accessed on 1 October 2018).

7. Ramo, J.C. The Beijing Consensus; Foreign Policy Centre: London, UK, 2004.

8. Huang, Y. Understanding China's Belt \& Road Initiative: Motivation, framework and assessment. China Econ. Rev. 2016, 40, 314-321.

9. Sandano, I.A. One Belt One Road: A Step Towards Globalization. Eurasian Economic Review. 2017. Available online: http:/ / www.eurasiareview.com/28032017-one-belt-one-road-a-step-towards-globalization-oped / (accessed on 1 October 2018).

10. De Bao, X. One Belt, One Road: China's reconstruction for global communication and international discourse power. International Institute for Asian Studies. 2016. Available online: http:/ /iias.asia/the-newsletter/article/ one-belt-one-road-chinas-reconstruction-global-communication-international (accessed on 1 October 2018).

11. Swaine, M.D. Chinese Views and Commentary on the "One Belt, One Road” Initiative. China Leadersh. Monit. 2015, 47, 1-24.

12. Zakaria, F. The Post-American World; W.W. Norton \& Company: New York, NY, USA, 2008.

13. Friedman, T.L. Hot, Flat, and Crowded 2.0: Why We Need a Green Revolution-And How It Can Renew America; Picador: London, UK, 2009.

14. Ferguson, N. Empire: The Rise and Demise of the British World Order and the Lessons for Global Power; Yale Global Online: New York, NY, USA, 2008.

15. Ikenberry, G.J. The Rise Future of China of and the West Can the Liberal System Survive? Foreign Aff. 2008, 87, 23-37.

16. Zheng, B. China's "peaceful rise" to great-power status. Foreign Aff. 2005, 84, 18-24.

17. Jia, W. Chiglobalization? A cultural argument. In Greater China in an Era of Globalization; Rowman \& Littlefield: Lanham, MD, USA, 2009; pp. 17-26.

18. The World Bank in China-Overview, World Bank. 2018. Available online: http://www.worldbank.org/en/ country/china/overview (accessed on 1 October 2018).

19. Tekdal, V. China's Belt and Road Initiative: At the crossroads of challenges and ambitions. Pac. Rev. 2018, 31, 373-390. [CrossRef]

20. Nicolas, F. China and the global economic order. A discreet yet undeniable contestation. China Perspect. 2016, 2, 7-14.

21. Güven, A.B. The World Bank and emerging powers: Beyond the multipolarity-multilateralism conundrum. New Polit. Econ. 2017, 22, 496-520. [CrossRef]

22. Callaghan, M.; Hubbard, P. The Asian infrastructure investment bank: Multilateralism on the silk road. China Econ. J. 2016, 9, 116-139. [CrossRef]

23. Ruwitch, J.; Blanchard, B. Exclusive-China Seeks to Cement Globalisation Credentials at Silk Road Summit; Reuters, 2017. Available online: https://www.reuters.com/article/us-china-silkroad-summitidUSKBN17S19C (accessed on 1 October 2018).

24. Jones, A.D.; Liu, H. Management of Chinese Foreign Direct Investment: “One Belt, One Road" across Eurasia to Africa and Europe Amidst Maritime Tensions in the South China Sea Region. Int. Relat. Diplomacy 2017, 5, 486-500.

25. Jia, W. Now, Globalization with Chinese Characteristics. Yale Global Online. 2017. Available online: http: / /yaleglobal.yale.edu/content/now-globalization-chinese-characteristics (accessed on 1 October 2018).

26. Lam, D. China and Europe: Winners in Globalization's New World Order. Atlneoc Bridge. 2017. Available online: http:/ /www.abven.com/news/china-and-europe-winners-in-globalizations-new-world-order (accessed on 1 October 2018).

27. Mingjiang, L. China's “One Belt, One Road” Initiative: New Round of Opening Up? RSIS Comment. 2015, 1, $1-2$.

28. Overholt, W.H. China and the evolution of the world economy. China Econ. Rev. 2016, 40, 267-271. [CrossRef]

29. Zeng, J. Is China committed to peaceful rise? Debating how to secure core interests in China. Int. Polit. 2017, 54, 618-636. [CrossRef]

30. Yu, H. Motivation behind China's 'One Belt, One Road' initiatives and establishment of the Asian infrastructure investment bank. J. Contemp. China 2017, 26, 353-368. [CrossRef]

31. Gill, B.; Huang, Y. Sources and limits of Chinese 'soft power'. Survival 2006, 48, 17-36. [CrossRef] 
32. Kurlantzick, J. Charm Offensive: How China's Soft Power Is Transforming the World; Yale University Press: New Haven, CT, USA, 2007.

33. Bruce-Lockhart, A. China's $\$ 900$ billion New Silk Road. What You Need to Know. Available online: https: / www.weforum.org/agenda/2017/06/china-new-silk-road-explainer/ (accessed on 1 October 2018).

34. The Asian Infrastructure Investment Bank: The Infrastructure Gap. Economist. 2015. Available online: http:/ / www.economist.com/node/21646740/print (accessed on 1 October 2018).

35. Mogato, M.; Petty, M. Push for South China Sea Code Stirs ASEAN Suspicions about Beijing's Endgame; Reuters, 2017. Available online: https://www.reuters.com/article/us-southchinasea-asean-analysisidUSKBN17T0A5 (accessed on 1 October 2018).

36. Shambaugh, D. China Goes Global: The Partial Power; Oxford University Press: Oxford, UK, 2013.

37. Holslag, J. How China's New Silk Road Threatens European Trade. Int. Spectator. 2017, 52, 46-60. [CrossRef]

38. Schultz, K. Sri Lanka, Struggling with Debt, Hands a Major Port to China. New York Times. 12 December 2017. Available online: https:/ / www.nytimes.com/2017/12/12/world/asia/sri-lanka-china-port.html (accessed on 1 October 2018).

39. Shukry, A.; Park, K. Malaysia Scraps Multibillion-Dollar High-Speed Rail Project to Singapore; Bloomberg, 2018. Available online: https:/ / www.bloomberg.com/news/articles/2018-05-28/mahathir-to-scrap-malaysiasingapore-high-speed-rail-project (accessed on 1 October 2018).

40. Anderlini, J.; Sender, H.; Bokhari, F. Pakistan rethinks its role in Xi's Belt and Road plan. Financial Times. 2018. Available online: https:/ / www.ft.com/content/d4a3e7f8-b282-11e8-99ca-68cf89602132 (accessed on 1 October 2018).

41. Boriçi, G. China's One Belt and One Road Initiative: The Response to Western Globalization? ILIRIA Int. Rev. 2018, 8, 1-14. [CrossRef]

42. Bijian, Z. China's "One Belt, One Road" Plan Marks the Next Phase of Globalization. New Perspect. Q. 2017, 27-31. [CrossRef]

43. Xi, J. Seek Sustained Development and Fulfill the Asia-Pacific Dream. In APEC China; 2014. Available online: https:/ / www.fmprc.gov.cn/mfa_eng/topics_665678/ytjhzzdrsrcldrfzshyjxghd/t1210456.shtml (accessed on 1 October 2018).

44. Alam, M.M. China' s Changing Strategic Engagements in Central Asia. J. Cent. Asian Stud. 2014, 21, 13.

45. Xihua, Vision and Actions on Jointly Building Silk Road Economic Belt and 21st-Century Maritime Silk Road. In Xihua; 2015. Available online: https:/ / eng.yidaiyilu.gov.cn/qwyw/qwfb/1084.htm (accessed on 1 October 2018).

46. Pencea, S. A look into the Complexities of the One Belt, One Road Strategy. Glob. Econ. Obs. 2017, 5, $142-158$.

47. Rolland, N. China's "Belt and Road Initiative": Underwhelming or Game-Changer? Wash. Q. 2017, 40, 127-142. [CrossRef]

48. Luft, G. It Takes a Road: China's One Belt One Road Initiative: An American Response to the New Silk Road, 2016. Available online: http:/ /www.iags.org/Luft_BRI.pdf (accessed on 1 October 2018).

49. Lehmacher, W. Why China Could Lead the Next Phase of Globalization; World Economic Forum, 2016. Available online: https:/ / www.weforum.org/agenda/2016/11/china-lead-globalization-after-united-states (accessed on 1 October 2018).

50. Brown, K. The Belt and Road: Security Dimensions. Asia Eur. J. 2018, 16, 213-222. [CrossRef]

51. Callahan, W.A. China's "Asia Dream" The Belt Road Initiative and the new regional order. Asian J. Comp. Polit. 2016, 1, 226-243. [CrossRef]

52. Jin, X.; Li, D.D.; Wu, S. How will China shape the world economy? China Econ. Rev. 2016, 40, $272-280$. [CrossRef]

53. Mohieldin, M. Belt and Road Initiative: A Global Effort for Local Impact. Connecting Cities for Inclusive and Sustainable Development; World Bank, 2017. Available online: https://www.worldbank.org/en/news/ feature/2017/09/26/bridge-for-cities-speech-by-mahmoud-mohieldin (accessed on 1 October 2018).

54. Bei, J. Economic Globalization 3.0 and the Concept of Interconnection under the belt and road initiative. China Econ. 2017, 12, 2-21.

55. Lai, T.L.; Tang, J.; Yin, H. Spatial Economics in the Era of One Belt One Road and Counter-Globalization. Mod. Econ. 2018, 9, 61-66. [CrossRef]

56. Amin, A.; Thrift, N. Globalization, Institutions, and Regional Development in Europe; Oxford University Press: Oxford, UK, 1995. 
57. Dreher, A. Does globalization affect growth? Evidence from a new index of globalization. Appl. Econ. 2006, 38, 1091-1110. [CrossRef]

58. Clark, W.C. Environmental Globalization. In Governance in a Globalizing World; Nye, J.S., Donahue, J.D., Eds.; Brookings Institution Press: Washington, DC, USA, 2000.

59. Norris, P. Global governance and cosmopolitan citizens. Governance in a Globalizing World. Available online: http:/ / unpan1.un.org/intradoc/groups/public/documents/apcity/unpan002060.pdf (accessed on 14 November 2018).

60. Vujakovic, P. How to Measure Globalisation? A New Globalisation Index (NGI); WIFO Working Papers; WIFO: Vienna, Austria, 2010; Volume 46, pp. 1-25.

61. Caselli, M. On the Nature of Globalization and its Measurement. Some Notes on the A.T. Kearney/Foreign Policy Magazine Globalization Index and the CSGR Globalization Index. In UNU-CRIS Occasional Papers; UNU-CRIS: Brugge, Belgium, 2006.

62. Hirst, P.; Thompson, G.; Bromley, S. Globalization in Question; John Wiley \& Sons: Hoboken, NJ, USA, 2015.

63. Perraton, D.; Goldblatt, D.; Held, A.; McGrew. The globalisation of economic activity. New Polit. Econ. 1997, 2, 257-277. [CrossRef]

64. Higgott, R. Economics, politics and (international) political economy: The need for a balanced diet in an era of globalization. New Polit. Econ. 1999, 4, 23-36. [CrossRef]

65. Hoogvelt, A. Globalization and the Postcolonial World: The New Political Economy of Development, 2nd ed.; Johns Hopkins University Press: Baltimore, MD, USA, 2001.

66. Farazmand, A. Globalization: A Theoretical Analysis with Implications for Governance and Public Administration; Public Administration and Public Policy: New York, NY, USA, 2007; Volume 129, p. 3.

67. Sheppard, E. The Limits to Globalization. The Disruptive Geographies of Global Development; Oxford University Press: Oxford, UK, 2016.

68. Xi, J. President Xi's speech at opening of Belt and Road forum. Xinhua. 2017. Available online: http: / /news.xinhuanet.com/english/2017-05/14/c_136282982.htm (accessed on 1 October 2018).

69. Ferdinand, P. Westward ho-the China dream and "one belt, one road": Chinese foreign policy under Xi Jinping. Int. Aff. 2016, 92, 941-957. [CrossRef]

70. Fair, C.C. ARGUMENT: Pakistan Can't Afford China's 'Friendship'. Foreign Policy. 2017. Available online: https:/ / foreignpolicy.com/2017/07/03/pakistan-cant-afford-chinas-friendship/ (accessed on 1 October 2018).

71. Yilmaz, S.; Changming, L. China's 'Belt and Road' Strategy in Eurasia and Euro-Atlanticism. Eur. Asia Stud. 2018, 70, 252-276. [CrossRef]

72. Xi, J. Xi Jinping delivers report to CPC congress. Xinhua. 2017. Available online: http:/ /www.chinadaily. com.cn/china/19thcpcnationalcongress/2017-10/18/content_33398037_5.htm (accessed on 1 October 2018).

73. Xi, J. Work Together to Build a Community of Shared Future for Mankind. Xinhua. 2017. Available online: http://news.xinhuanet.com/english/2017-01/19/c_135994707.htm (accessed on 1 October 2018).

74. Straumann, B. The peace of Westphalia as a secular constitution. Constellations 2008, 15, 173-188. [CrossRef]

75. Kuhn, R.L. Shared development as the last concept. China Daily. 2016. Available online: http://www. chinadaily.com.cn/opinion/2016-11/12/content_27355752.htm (accessed on 1 October 2018).

76. Cheng, L.K. Three questions on China's Belt and Road Initiative. China Econ. Rev. 2016, 40, $309-313$. [CrossRef]

77. Yi, H. China's One Belt/One Road' Policy Is Open to All Nations. Executive Intelligence Review. 2015. Available online: http:/ /schillerinstitute.org/economy/phys_econ/2015/27-29_EIR12-ne_belt_one_road. html (accessed on 1 October 2018).

78. Keming, Q. China sees trade, investment growth with B\&R countries. In Xinhua News Agency; 2018. Available online: https: / eng.yidaiyilu.gov.cn/ qwyw / rdxw / 64034.htm (accessed on 1 October 2018).

79. Boffa, M. Trade Linkages between the Belt and Road Economies. Policy Research Working Paper. 2018. Available online: https:/ / openknowledge.worldbank.org/handle/10986/29768 (accessed on 14 November 2018).

80. Yi, W. China's Belt and Road initiatives not solo, but symphony. Xinhua. 2015. Available online: http: / / usa.chinadaily.com.cn/us/2015-03/08/content_19752472.htm (accessed on 1 October 2018).

81. Xi, J. Asia's New Future: Towards a Community of Common Destiny. Boao Forum for Asia Annual Conference 2015, Boao Forum. 2015. Available online: http:/ / english.boaoforum.org/u/cms/www2/201503/ 25112018qw3q.pdf (accessed on 14 November 2018). 
82. Johns, B.M.; Clarke, J.L.; Mclinden, C.G. Trade Facilitation Challenges and Reform Priorities for Maximizing the Impact of the Belt and Road Initiative; The World Bank: Washington, DC, USA, 2018.

83. Xi, J. Shared future for all a win-win concept. China Daily. 2017. Available online: https:/ /www.chinadaily. com.cn/opinion/2017-03/25/content_28675525.htm (accessed on 1 October 2018).

84. Pantucci, R.; Lain, S. China's Eurasian Pivot: The Silk Road Economic Belt; Routledge: London, UK, 2017.

85. Clemens, M. The Maritime Silk Road and the PLA: Part One \& Part Two. China Brief. 2015, 15, 1-7.

86. Swaine, M.D. Chinese views and commentary on periphery diplomacy. China Leadership Monitor. 2014, 44, 1-43.

87. Tracy, E.F.; Shvarts, E.; Simonov, E.; Babenko, M. China' s new Eurasian ambitions: The environmental risks of the Silk Road Economic Belt. Eurasian Geogr. Econ. 2017, 58, 56-88. [CrossRef]

88. Kley, D. China shifts polluting cement to Tajikistan. China Dialogue. 2016. Available online: https://www. chinadialogue.net/article/show/single/en/9174-China-shifts-polluting-cement-to-Tajikistan (accessed on 1 October 2018).

89. How China cut its Air Pollution. The Economist. 2018. Available online: https://www.economist.com/theeconomist-explains /2018/01/25/how-china-cut-its-air-pollution (accessed on 1 October 2018).

90. Cai, K.G. The One Belt One Road and the Asian Infrastructure Investment Bank: Beijing's New Strategy of Geoeconomics and Geopolitics. J. Contemp. China 2018, 27, 1-17. [CrossRef]

91. Cho, Y.N.; Jeong, J.H. China's Soft Power: Discussions, Resources, and Prospects. Asian Surv. 2008, 48, 453-472. [CrossRef]

92. Shan, W. The "Silk Road Spirit" in a Time of Globalization; Oxford University Press: Oxford, UK, 2016.

93. Yiwei, W. One belt one road: Opportunities for Europe-China cooperation. Europe's World. 2015. Available online: https:/ / www.friendsofeurope.org/global-europe/one-belt-one-road-opportunities-europe-chinacooperation (accessed on 1 October 2018).

94. Assadi, M.Z. One Belt One Road is a new form of globalization, China. Caspian Times. 2017. Available online: http:/ / www.thecaspiantimes.com/one-belt-one-road-new-form-globalization-china/ (accessed on 1 October 2018).

95. Pardo, R.P. Europe's financial security and Chinese economic statecraft: The case of the Belt and Road Initiative. Asia Eur. J. 2018, 16, 237-250. [CrossRef]

96. Newsletter. Is China's Globalization the New Pacesetter? Views from China's State Finance Managers; CCR Advisory Group, 2016. Available online: https://ccradvisorygroup.com/chinas-globalization-newpacesetterviews-chinas-state-finance-managers (accessed on 1 October 2018).

97. Liu, W.; Dunford, M. Inclusive globalization: Unpacking China's Belt and Road Initiative. Area Dev. Policy 2016, 1, 323-340. [CrossRef]

98. Xinhua. China's investment to Belt and Road countries exceeds 50 bln USD: Official. Xinhua. 2017. Available online: http:/ / news.xinhuanet.com/english/2017-03/06/c_136106367.htm (accessed on 1 October 2018).

(C) 2018 by the authors. Licensee MDPI, Basel, Switzerland. This article is an open access article distributed under the terms and conditions of the Creative Commons Attribution (CC BY) license (http://creativecommons.org/licenses/by/4.0/). 